\title{
A simple carbon offset scenario tool (COST) for assessing dairy farm abatement options
}

\author{
K.M. Christie ${ }^{\text {a }}$, M.T. Harrison ${ }^{\text {a }}$, R.P. Rawnsley ${ }^{\text {a }}$ and R.J. Eckard ${ }^{\text {b }}$ \\ ${ }^{a}$ Tasmanian Institute of Agriculture, University of Tasmania, Burnie, TAS 7320 Australia \\ ${ }^{b}$ Melbourne School of Land and Environment, University of Melbourne, Melbourne, VIC 3010 Australia \\ Email: Matthew.Harrison@utas.edu.au
}

\begin{abstract}
The dairy Carbon Offset Scenario Tool (COST) was developed to explore the influence of various abatement strategies on greenhouse gas (GHG) emissions for Australian dairy farms. COST is a static spreadsheet-based tool that uses Australian GHG inventory methodologies, algorithms and emission factors to estimate carbon dioxide, methane and nitrous oxide emissions of a dairy farm system. One of the key differences between COST and other inventory-based dairy GHG emissions calculators is the ability to explore the effect of reducing total farm emissions on farm income, assuming the strategy was compliant with Kyoto rules for carbon offsets.

COST provides ten abatement strategies across the four broad theme areas of diet manipulation, herd and breeding management, feedbase management and waste management. Each abatement strategy contains four sections; two sections for data entry (baseline farm data specific to the strategy explored and strategy-specific variables) and two sections for results (milk production results and GHG/economic-related results). Key sensitive variables for each strategy, identified from prior research, and prices for milk production and carbon offsets are adjusted through up/down buttons, which allows users to quickly explore the impact of these variables on farm emissions and profitability. For example, if the cost to implement an abatement strategy is doubled, what carbon offset income would be required to negate this additional cost? Results are presented as changes in carbon offset income, strategy implementation cost, additional milk production income and net farm income on a per annum and on a per GHG emissions intensity of milk production basis.
\end{abstract}

COST currently contains a comprehensive range of strategies for GHG abatement, although some strategies are still in development. As new technologies or farm management practices leading to a reduction in GHG emission become available, these too will be incorporated into COST. To date, two dairy-specific abatement methodologies have been legislated as part of Australia's commitment to reducing on-farm GHG emissions through it's the carbon offset scheme, the Carbon Farming Initiative (CFI) and are incorporated into COST. These are the 'Destruction of methane generated from dairy manure in covered anaerobic ponds' and the 'Methodology for reducing greenhouse gas emissions in milking cows through feeding dietary additives'.

As an example, we explored the mitigation option Replace supplements with a source of dietary fats (reflecting the second above-mentioned CFI legislated abatement strategy) as feeding a diet higher in dietary fats has been shown to reduce enteric methane emissions per unit of feed intake. A 400 milking herd was fed a baseline diet of $2.6 \%$ dietary fat. By replacing grain with hominy meal, at a rate of $5.0 \mathrm{~kg}$ dry matter/ cow per day for 90 days during the 3 summer months, the summer diet fat concentration was increased to $6.4 \%$. Enteric methane emissions were reduced by 40 tonnes of carbon dioxide equivalents $\left(\mathrm{t}_{2} \mathrm{e}\right)$ per annum for

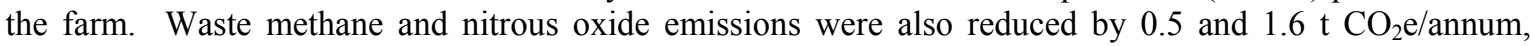
respectively. However, as reductions from these two sources of GHG emissions do not qualify for payment with this CFI methodology, their reduction could not be included as an offset income. At a carbon price of $\$ 20 / \mathrm{t} \mathrm{CO}_{2} \mathrm{e}$, the reduction in enteric methane emissions was valued at $\$ 800 / \mathrm{farm}$. The implementation cost of replacing grain with hominy was valued at $\$ 18,000 /$ farm due to the hominy meal costing an additional $\$ 100 / t$ dry matter compared to the grain. However, the additional milk production achieved due to the higher energy concentration of the diet resulted in an additional 70,200 litres and based on a summer milk price of $\$ 0.38 /$ litre, this equated to an additional income from milk valued at $\$ 26,676 / \mathrm{farm}$. The overall result was a net increase in farm profit of $\$ 9,476 /$ farm when paid on a reduction in total GHG emissions. COST can quickly allow users to ascertain the level of GHG emission reduction possible with various mitigation options and explore the sensitivity of key variables on GHG emissions and farm profitability.

Keywords: Carbon offsets, dairy, greenhouse gas emissions, methane, nitrous oxide 


\section{INTRODUCTION}

Emissions of greenhouse gases (GHG) from Australian agriculture in 2011/2012 constituted some 15\% of the nation's total annual GHG emissions (DIICCSTRE, 2013a). The agricultural sector contributes 57 and 76\% of the nation's methane $\left(\mathrm{CH}_{4}\right)$ and nitrous oxide $\left(\mathrm{N}_{2} \mathrm{O}\right)$ emissions, respectively (DIICCSTRE, 2013b). Enteric fermentation from livestock account for $\sim 85 \%$ of agricultural $\mathrm{CH}_{4}$ emissions (DIICCSTRE, 2013b) while emissions from livestock and nitrogen $(\mathrm{N})$ fertilisers account for $\sim 76 \%$ of the nation's $\mathrm{N}_{2} \mathrm{O}$ emissions (DIICCSTRE, 2013b). As such, there is an imperative to reduce GHG emissions derived from the Australian agricultural sector, with the Federal Government introducing a carbon offset scheme in 2011 called the Carbon Farming Initiative (CFI) to create opportunities for land managers to enhance productivity, obtain economic benefits and help the environment by sequestering carbon or by reducing/avoiding GHG emissions (DIICCSTRE, 2013a).

A number of GHG abatement options have been explored for various livestock industries, including dairy (Beukes et al., 2010; Eckard et al., 2010; Browne et al., 2011; Patra, 2012; Misselbrook et al. 2013). Enteric $\mathrm{CH}_{4}$ mitigation options can broadly be categorised into theme areas of animal intervention (e.g. selection of animals with a lower enteric $\mathrm{CH}_{4}$ emission per unit of feed intake), dietary interventions (feeding dietary lipids) and the suppression of rumen methanogens (e.g. vaccination). Examples of enteric $\mathrm{CH}_{4}$ abatement studies include Hegarty et al. (2007) who found that enteric $\mathrm{CH}_{4}$ emissions $\left(\mathrm{g} \mathrm{CH}_{4} /\right.$ head/day) were $26 \%$ lower in steers with a lower residual feed intake and Moate et al. (2011) who found that for every $1 \%$ increase in dietary fat concentration, enteric $\mathrm{CH}_{4}$ emissions were reduced by $3.5 \%$.

Abatement options for reducing $\mathrm{N}_{2} \mathrm{O}$ emissions can be broadly categorised into theme areas of diet manipulations (e.g. feeding of condensed tannins), herd management (e.g. breeding animals with improved $\mathrm{N}$ use efficiency) or feedbase management (e.g. improved $\mathrm{N}$ fertiliser management). Examples of research results from $\mathrm{N}_{2} \mathrm{O}$ abatement studies include de Klein et al. (2011) who showed that application of nitrification inhibitors to dairy urine patches reduced $\mathrm{N}_{2} \mathrm{O}$ emissions from $\sim 14.4$ to $4.5 \mathrm{~kg} \mathrm{~N} \mathrm{~N}_{2} \mathrm{O}-\mathrm{N} / \mathrm{ha}$, and Misselbrook et al. (2005) who showed that dairy cows fed a diet consisting of $3.5 \%$ condensed tannins excreted $25 \%$ less urinary $\mathrm{N}$ compared to cows on a $1 \%$ condensed tannin diet.

In reporting these reductions in GHG emissions, what is not necessarily explored is the cost of implementing these strategies and whether these costs could be negated if the reduction in GHG emissions was offset via a carbon credit system. The dairy Carbon Offset Scenario Tool (COST) was developed to explore the influence of various abatement strategies on greenhouse gas (GHG) emissions for Australian dairy farms, with the potential that any reduction in GHG emissions be credited as part of a carbon offset scheme. This paper describes the structure of the Dairy COST calculator and explores a case study of applying feeding a source of high dietary fat to reduce enteric $\mathrm{CH}_{4}$ per unit of feed intake as an abatement strategy for a typical dairy farm in south-eastern Australia.

\section{DAIRY COST DESCRIPTION}

Dairy COST is a static spreadsheet-based tool that uses Australian National Greenhouse Gas Inventory (NGGI) methodologies, algorithms and emission factors to estimate carbon dioxide $\left(\mathrm{CO}_{2}\right), \mathrm{CH}_{4}$ and $\mathrm{N}_{2} \mathrm{O}$ emissions for a dairy farm system (DCCEE, 2012). $\mathrm{CH}_{4}$ and $\mathrm{N}_{2} \mathrm{O}$ emissions are converted into global warming potentials in $\mathrm{CO}_{2}$ equivalents $\left(\mathrm{CO}_{2} \mathrm{e}\right)$ of 21 and 310, respectively (DCCEE, 2012). COST contains a data entry worksheet where the baseline farm data are entered and the results are presented in tabulated and graphic form (Figure 1). Another worksheet contains a decisions tree with the four theme areas and ten abatement strategies within each theme area (Figure 1). In this sheet users can select an individual abatement strategy from the decision tree, allowing them to link to the corresponding worksheet that allows analysis of particular abatement strategies (Figure 2).

\section{ENTERING DATA INTO COST AND ANALYSING RESULTS}

Within each abatement strategy there are four main data entry/calculation sections (Figure 3). The first section (highlighted in green) contains relevant baseline data for the dairy farm under investigation. Examples of data include milking herd size, amount of $\mathrm{N}$ fertiliser applied to pastures or the number of heifers less than one year of age. This baseline data gives the user a reference point to which the abatement strategy explores the relative effect upon. For example, the Extended herd longevity to reduce replacement rates abatement strategy requires the user to alter the baseline number of heifers in order to examine the relative effect of this variable on farm GHG emissions. 
The second section (highlighted in pink; Figure 3) lists the strategy input variables required to be assess/ altered as required by the user (Figure 3). These inputs form the basis for estimating the influence of the abatement strategy on reducing either total GHG emissions or the GHG emissions intensity of milk production ( $\mathrm{kg} \mathrm{CO}_{2} \mathrm{e} /$ litre milk). Two input variables that feature in all abatement strategies are the average annual milk price $\left(\$ /\right.$ litre milk) and the carbon price $\left(\$ / \mathrm{t} \mathrm{CO}_{2} \mathrm{e}\right)$. In addition, some of the abatement strategies also include a second average milk price for when the abatement strategy is implemented. For example, using a nitrification inhibitor in autumn/ winter could result in additional pasture production being converted into additional milk at price higher than the average annual milk price.

The third section in COST (highlighted in purple; Figure 3) is calculated data informing the users of changes to non-GHG related aspects of the abatement strategy, such as increased milk production per cow. The last section in COST (highlighted in blue; Figure 3) is the Summary Table and is consistent for all abatement strategies. Reductions in GHG emissions relative to the baseline farm are reported as positive numbers. Conversely, negative numbers represent situations leading to increased GHG emissions. COST computes the relative difference between the baseline abatement strategy farms during the period of implementation and then multiplies this by the carbon price to estimate an income akin to the carbon offset scheme income.

Results are also presented graphically (not shown here due to limited space). Total farm benefit is computed as the sum of the carbon offset income and any additional milk income minus implementation cost. Each set of monetary values (i.e. carbon offset income, implementation cost, additional income and total farm benefit) has two columns; one for the changes in income and expenses based on a reduction in total farm GHG emissions (blue columns) and one for the changes in income and expenses based on a reduction in the GHG emissions intensity of milk production (red columns).

Australia's carbon offset scheme, as it is currently legislated, only credits reductions in total farm GHG emissions. Reductions in the GHG emissions intensity of production cannot generate a carbon offset unless it leads to a net reduction in emissions. While some of the abatement strategies incorporated in COST would not qualify for the carbon offset scheme, in developing COST we wanted to also ascertain how changes to farm management might result in a reduction in GHG emissions intensity and be profitable for farmers. An example of such is Improve diet digestibility through management. For this strategy total farm GHG emissions will increase because improved diet digestibility leads to increases in daily intakes, enteric $\mathrm{CH}_{4}$ emissions and milk production (DCCEE, 2012) in addition to potentially greater farm profitability and lowering of the emission intensity of milk production.

\section{A CASE STUDY OF ABATEMENT POTENTIAL USING COST}

Figure 3 shows an example of the Replace supplements with a source of dietary fats abatement strategy which has been approved as an Australian carbon offset methodology. The estimation of GHG emissions in COST was based on the carbon-offset methodology (DIICCSTRE, 2013c) as opposed to the NGGI methodology (DCCEE, 2012). The baseline farm was adapted from Moate et al. (2011) and contained 400 milking cows that weighed $600 \mathrm{~kg}$ and produced an average of 21.4 litres/ day over summer from an average annual diet of $71.0 \%$ dry matter digestibility (DMD) and a crude protein (CP) concentration of $18.4 \%$. To simplify the farm system, there were no replacement heifers or bulls present, no $\mathrm{N}$ fertiliser inputs and no electricity or diesel consumption, so the GHG emissions reflected only those from the milking herd. Enteric $\mathrm{CH}_{4}$ emissions represent the largest source of emissions at $1,276 \mathrm{t} \mathrm{CO}_{2} \mathrm{e} /$ annum; equivalent to $73 \%$ of the milking herd's total GHG emissions.

The baseline diet had a dietary fat concentration of $2.6 \%$ thus giving scope to feed a high dietary fat supplement up to the 6-7\% dietary fat limit before milk depression occurs (Eckard et al. 2010). Hominy meal replaced cracked grain fed in the dairy parlour, with $5.0 \mathrm{~kg}$ dry matter (DM) fed/cow.day for 90 days during summer. The cracked grain had a DMD of $85.0 \%$, a CP of $18.0 \%$, dietary fat concentration of $2.1 \%$ and cost $\$ 250 / \mathrm{t} \mathrm{DM}$. The hominy meal had a DMD of $86.5 \%$, CP of $14.6 \%$, dietary fat concentration of $16.1 \%$ and cost $\$ 350 / \mathrm{t}$ DM. Over summer the average milk price was $\$ 0.38 /$ litre and the carbon offset price was $\$ 20 / \mathrm{t}$ $\mathrm{CO}_{2} \mathrm{e}$.

Replacing the cracked grain with hominy meal increased the dietary fat concentration of the total diet to $6.4 \%$ during the 90-day mitigation period and increased daily energy intakes by 10.7 Megajoules (MJ) of energy/cow.day. Enteric $\mathrm{CH}_{4}$ emissions were reduced by 40.0 t $\mathrm{CO}_{2} \mathrm{e} / \mathrm{farm}$. Although waste $\mathrm{CH}_{4}$ and $\mathrm{N}_{2} \mathrm{O}$ emissions were also reduced by 0.5 and $1.6 \mathrm{t} \mathrm{CO}_{2} \mathrm{e} /$ farm, respectively, due to improved diet digestibility and reduced diet crude protein concentrations, only reductions in enteric $\mathrm{CH}_{4}$ emissions, minus any increases in urine and faeces $\mathrm{CH}_{4} / \mathrm{N}_{2} \mathrm{O}$ emissions, can be credited with this carbon offset methodology. Therefore the net reduction in GHG emissions was valued at $\$ 800$ /farm over the 90-day mitigation period (Figure 3). 


\section{Dairy Carbon Offset Scenario Tool}

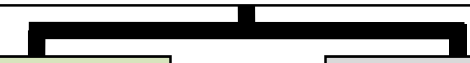

\section{Data entry for a baseline farm system}

- Farm location (state) and average annual rainfall

- Milking herd numbers, live weight, milk production, lactation length, diet digestibility and crude protein $\%$

- Number of heifers, live weight, live weight gain, diet digestibility and

crude protein \%

- Number of bulls, live weight, live weight gain, diet digestibility and crude protein \%

- Area of farm cropped and improved pastures

- Nitrogen fertiliser rates for crops and pastures

- Diesel and Electricity source and consumption

- Tree plantations (area and species)
Greenhouse gas emission estimation methodology and results:

- Based on Australian National Greenhouse Gas Inventory

o Enteric methane

o Methane from waste management

o Nitrous oxide from waste management (direct and indirect)

o Nitrous oxide from $\mathrm{N}$ fertilisers (direct and indirect)

o Carbon dioxide from electricity and diesel consumption

○ Carbon dioxide sequestered in tree plantations

- Results presented as total farm GHG emissions and GHG emissions

intensity of milk production

- Graphical representation of each emissions source

- Percentage contribution from each emissions source and stock class

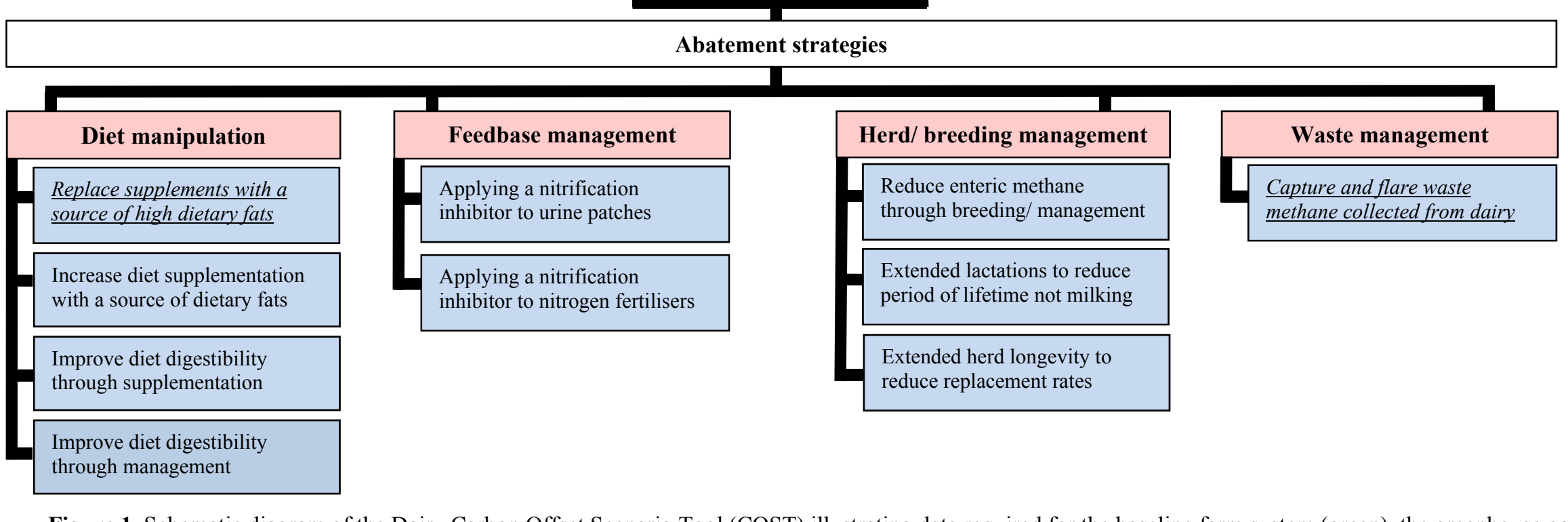

Figure 1. Schematic diagram of the Dairy Carbon Offset Scenario Tool (COST) illustrating data required for the baseline farm system (green), the greenhouse gas emissions estimated by the tool (grey), results presented (yellow), four abatement theme areas (pink) and ten individual abatement strategies (blue). The two abatement strategies in italics have been legislated by the Australian Government as carbon offset abatement options for the Australian dairy industry. 


\begin{tabular}{|c|}
\hline Diet manipulation \\
\hline $\begin{array}{l}\text { Replace supplements with a source of high dietary fats } \\
\text { - Average annual dietary fat } \% \text { of the baseline diet } \\
\text { - Amount, cost and quality (digestibility, crude protein and fat) \% of the supplement to be replaced } \\
\text { - Cost and quality (digestibility, crude protein and fat) } \% \text { of the high dietary fat supplement } \\
\text { - Number of days per annum the high dietary fat supplement is fed per annum } \\
\text { - Average annual milk price, price of milk during the mitigation period and on-farm price for carbon }\end{array}$ \\
\hline $\begin{array}{l}\text { Increase diet supplementation with a source of dietary fats } \\
\text { - Average annual dietary fat } \% \text { of the baseline diet } \\
\text { - Amount, cost and quality (digestibility, crude protein and fat) \% of the new supplement } \\
\text { - Number of days per annum the high dietary fat supplement is fed per annum } \\
\text { - Estimated substitution rate of the new high dietary fat supplement } \\
\text { - Average annual milk price, price of milk during the mitigation period and on-farm price for carbon }\end{array}$ \\
\hline $\begin{array}{l}\text { Improve diet digestibility through supplementation } \\
\text { - Amount, cost, quality (digestibility and crude protein) \% of the new higher digestibility supplement } \\
\text { - Estimated substitution rate of the new higher digestibility supplement } \\
\text { - Average annual milk price, price of milk during the mitigation period and on-farm price for carbon }\end{array}$ \\
\hline $\begin{array}{l}\text { Improve diet digestibility through management } \\
\text { - Quality (digestibility and crude protein) \% of the abatement strategy diet } \\
\text { - Number of days per annum the milking herd is fed the abatement strategy diet } \\
\text { - Cost per annum to implement the higher digestibility diet } \\
\text { - Average annual milk price, price of milk during the mitigation period and on-farm price for carbon }\end{array}$ \\
\hline Feedbase management \\
\hline $\begin{array}{l}\text { Applying a nitrification inhibitor to urine patches } \\
\text { - Percentage of time cows spend grazing pastures per annum } \\
\text { - Number of days per annum the nitrification inhibitor is effective, efficacy and cost of the nitrification inhibitor } \\
\text { - On-farm price for carbon }\end{array}$ \\
\hline $\begin{array}{l}\text { Applying a nitrification inhibitor to nitrogen fertilisers } \\
\text { - Percentage of annual } \mathrm{N} \text { fertiliser that is coated with the nitrification inhibitor } \\
\text { - Number of days per annum and effectiveness (\%) of the nitrification inhibitor } \\
\text { - Cost of the uncoated (baseline) and coated (abatement strategy) } \mathrm{N} \text { fertiliser } \\
\text { - Area of farm applied with the nitrification inhibitor and yield, quality (digestibility) and utilization of } \\
\text { additional pasture grown } \\
\text { - Average annual milk price, price of milk during the mitigation period and on-farm price for carbon }\end{array}$ \\
\hline Herd/ breeding management \\
\hline $\begin{array}{l}\text { Reduce enteric methane emissions through breeding or management } \\
\text { - Percentage reduction in enteric methane emissions and what } \% \text { of this is converted into milk } \\
\text { - Cost and number of days per annum the strategy is effective } \\
\text { - Average annual milk price and on-farm price for carbon }\end{array}$ \\
\hline $\begin{array}{l}\text { Extended lactations to reduce period of lifetime not milking } \\
\text { - Starting date (calving date) of the abatement strategy (same as for the baseline) } \\
\text { - Average daily milk production per cow for the primiparous and multiparous extended lactation cows } \\
\text { - Average lactation length and number of days non-lactating for the extended lactation herd } \\
\text { - Number of extended lactations before culling } \\
\text { - Average annual milk price and on-farm price for carbon }\end{array}$ \\
\hline $\begin{array}{l}\text { Extended herd longevity to reduce replacement rates } \\
\text { - Number of rising one and rising two year olds and cost to raise each heifer to point of calving } \\
\text { - Average annual milk price and on-farm price for carbon }\end{array}$ \\
\hline Waste management \\
\hline $\begin{array}{l}\text { Capturing and flaring of manure deposited in the dairy } \\
\text { - This abatement strategy is being re-designed to align with the legislated carbon offset methodology }\end{array}$ \\
\hline
\end{tabular}

Figure 2. Input variables for each abatement strategy. The two abatement strategies in italics have been legislated by the Australian Government as carbon offset abatement options for the Australian dairy industry. 
Replacing grain with hominy meal resulted in an implementation cost of $\$ 18,000 /$ farm due to the higher cost of the hominy meal compared to the grain. In this example, the cost to implement the abatement strategy was substantially greater than the income from the carbon offset. However, replacing grain with hominy meal improved the energy density of the diet. Based on the assumption that each additional litre of milk requires 5.5 MJ of metabolisable energy (MAFF, 1984), an additional 70,200 litres of milk was produced from the herd over the summer months. With a milk price of $\$ 0.38 /$ litre, this resulted in an additional milk income of $\$ 26,676$ / farm (Figure 3). The net total farm benefit of implementing this strategy was valued at $\$ 9,476 /$ farm; equivalent to $0.9 \%$ of the baseline milk income (Figure 3). This strategy also resulted in a reduction in the GHG emissions intensity of milk production of $0.09 \mathrm{~kg} \mathrm{CO}_{2} \mathrm{e} /$ litre milk over the 12 month period (Figure 3 ). If this reduction in GHG emissions intensity was credited as part of a carbon offset scheme, the reduction in GHG emissions intensity would be valued at $\$ 1,148 /$ farm based on a carbon price of $\$ 20 / t \mathrm{CO}_{2} \mathrm{e}$. Implementation costs and additional milk income would not alter, resulting in a net total farm benefit of $\$ 9,824$ /farm (Figure 3).

\begin{tabular}{|c|c|c|c|}
\hline Baseline number of milkers & & 400 & \\
\hline Average liveweight of milking cow $[\mathrm{kg}$ ) & & 600 & \\
\hline Current milk production (litrestcow.day) & & 21.4 & \\
\hline Average lactation length (days] & & 300 & \\
\hline Digestibility of the baseline diet [\%] & & 71.0 & \\
\hline Crude protein of the baseline diet [\%] & & 18.4 & \\
\hline Enter estimated fat content of the baseline diet $[\%]$ & $\mathbf{v}$ & 2.6 & $\doteqdot$ \\
\hline Enter amount of baseline supplement to be replaced (kg DWWcow.day) & & 5.0 & $\div$ \\
\hline Enter digestibility of baseline supplement to be replaced $[\%]$ & & 85.0 & $\because$ \\
\hline Enter crude protein of the baseline supplement to be replaced $[\%]$ & & 18.0 & $\div$ \\
\hline Enter fat content of baseline supplement to be replaced [\%] & & 2.1 & $\div$ \\
\hline Enter cost of baseline supplement to be replaced (\$t DM) & & 250 & $\div$ \\
\hline Enter digestibility of the new abatement strategy supplement [\%] & & 86.5 & $\div$ \\
\hline Enter crude protein of the new abatement strategy supplement [\%] & & 14.6 & $\div$ \\
\hline Enter fat content of the new abatement strategy supplement [\%] & & 16.1 & $\div$ \\
\hline Enter cost of new abatement strategy supplement [ $\$$. DM] & & 350 & $\div$ \\
\hline Enter number of days per year the new abatement supplement is fed & & 90 & $\div$ \\
\hline Enter average annual milk price [ $\$$ litre] & $\mathbf{v}$ & $\$ 0.400$ & $\div$ \\
\hline Enter milk price for when supplements fed (\$Nlitre) & V & $\$ 0.380$ & $\because$ \\
\hline Enter on farm price received for a t $\mathrm{CO} 2 \mathrm{e}(\$)$ & $\mathbf{v}$ & $\$ 20.00$ & $\div$ \\
\hline Estimated fat content in the abatement strategy diet during the activation period $(\%)$ & & 6.41 & \\
\hline Estimated additional milk produced (litresffarm) & & 70,200 & \\
\hline \multicolumn{4}{|l|}{ Summary Table } \\
\hline Reduction in enteric CH4 emissions [t CO2elannum] & & 40.0 & \\
\hline Reduction in animal waste CH4 emissions [t CO2edannum] & & 0.5 & \\
\hline Reduction in animal waste N2O emissions [t CO2ełannum] & & 1.6 & \\
\hline Reduction in N fertiliser N2O emissions [t CO2edannum] & & 0.0 & \\
\hline Total reduction in farm GHG emissions [t CO2elannum] & 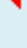 & 40.0 & \\
\hline Calculated potential CFI income [\$ per farm] & & $\$ 800$ & \\
\hline Calculated cost to implement the strategy [ $\$$ per farm] & & $\$ 18,000$ & \\
\hline Benefit as stand alone abatement [\$ per farm] & & $-\$ 17,200$ & \\
\hline Estimated additional milk income [\$ per farm] & & $\$ 26,676$ & \\
\hline Estimated total farm benefit from strategy [\$ per farm] & & $\$ 9,476$ & \\
\hline CFI total farm benefit income as \% of current milk income & \ & $0.9 \%$ & \\
\hline Reduction in emission intensity [kg CO2-ellitre of milk] & $\mathbf{v}$ & 0.09 & \\
\hline \multirow{2}{*}{\multicolumn{2}{|c|}{$\begin{array}{l}\text { Calculated potential CFI income if paid on reduced GHG emissions intensity [ } \$ \mathrm{HFarm} \text { ] } \\
\text { Estimated total benefit if paid on reduced GHG emissions intensity [\$farm] }\end{array}$}} & $\$ 1,148$ & \\
\hline & & $\$ 9,824$ & \\
\hline
\end{tabular}

Figure 3. Schematic diagram illustrating the Replace supplements with a source of high dietary fats abatement strategy. Included are the two data entry sections (baseline farm highlighted green and variables highlighted pink) and two result sections (milk-related results highlighted purple and GHG/ economics results highlighted blue). 


\section{DISCUSSION AND CONCLUSIONS}

COST gives users an insight into the likely reductions in GHG emissions and emissions intensity achievable from a range of abatement strategies for the Australian dairy industry. Unlike other inventory-based dairy GHG emissions calculators (e.g. DGAS; Christie et al., 2012), users can alter key variables using up/down buttons to examine the influence of changing strategy-related variables, costs, prices, carbon offset credits and farm management practices on GHG mitigation potential and its influence on farm profits relative to a baseline farm. Our case study revealed that the management practice of feeding dietary fats resulted in an improvement in farm productivity, with the resultant milk income greater by an order of magnitude than from the carbon offset income. Several of the abatement strategies in COST may never meet the stringent integrity standards of the CFI carbon offset scheme, particularly in terms of additionality and leakage. However, dairy COST can be used to guide decisions on improving the emissions intensity of production, thus marketing milk with lower embedded GHG emissions.

\section{ACKNOWLEDGMENTS}

This project was supported by funding from Dairy Australia, Meat and Livestock Australia, Australian Wool Innovation and the Australian Government Department of Agriculture, Fisheries and Forestry under its Australia's Farming Future Climate Change Research Program.

\section{REFERENCES}

Beukes, P.C., Gregorini, P., Romera, A.J., Levy, G. and Waghorn, G.C. (2010). Improving production efficiency as a strategy to mitigate greenhouse gas emissions on pastoral dairying systems in New Zealand. Agriculture Ecosystems \& Environment, 136, 358-365

Browne, N.A., Eckard, R.J., Behrendt, R. and Kingwell, R.S. (2011). A comaprative analysis of on-farm greenhouse gas emissions from agricultureal exterprises in south eastern Australia. Animal Feed Science and Technology, 166/167, 641-652.

Christie, K.M., Gourley, C.J.P., Rawnsley, R.P., Eckard, R.J. and Awty, I.M. (2012). Whole-farm systems analysis of Australian dairy farm greenhouse gas emissions. Animal Production Science, 52, 998-1011.

DCCEE (2012). National Inventory Report 2010: The Australian Government Submission to the UN Framework Convention on Climate Change April 2012, vol. 1. Department of Climate Change and Energy Efficiency, Canberra, ACT, Australia.

de Klein, C.A.M., Cameron, K.C., Di, H.J., Rys, G., Monaghan, R.M. and Sherlock, R.R. (2011). Repeated annual use of the nitrification inhibitor dicyandiamide (DCD) does not alter its effectiveness in reducing $\mathrm{N}_{2} \mathrm{O}$ emissions from cow urine. Animal Feed Science and Technology, 166/167, 480-491.

DIICCSTRE (2013a). Department of Climate Change and Energy Efficiency 2012, Agriculture emissions projections 2012, DIICCSTRE, Canberra, ACT. Available: http://www.climatechange.gov.au [Accessed 29 May 2013].

DIICCSTRE (2013b). Australian Greenhouse Emissions Information System, DIICCSTRE, Canberra, ACT. Available: http://ageis.climatechange.gov.au//Accessed 29 May 2013].

DIICCSTRE (2013c). Carbon Farming Initiative Methodologies, DIICCSTRE, Canberra, ACT. Available: http:/www.climatechange.gov.au/reducing-carbon/carbon-farming-initiative/methodologies [29 May 2013].

Eckard, R.J., Grainger, C. and de Klein, C.A.M. (2010) Options for the abatement of methane and nitrous oxide from ruminant production: A review. Livestock Science, 130, 47-56.

Hegarty, R.S., Goopy, J.P., Herd, R.M. and McCorkell, B. (2007). Cattle selected for lower residual feed intake have reduced daily methane production. Journal of Animal Science, 85, 1479-1486.

MAFF (1984) Energy allowances and feeding systems for ruminants. Ministry of Agriculture, Fisheries and Food, Her Majesty's Stationery Office, London, United Kingdom.

Misselbrook, T.H., Powell, J.M., Broderick, G.A. and Grabber, J.H. (2005) Dietary manipulation in dairy cattle: laboratory experiments to assess the influence on ammonia emissions. Journal of Dairy Science, 88, 1765-1777.

Misselbrook, T., del Prado, A. and Charwick, D. (2013). Opportunities for reducing environmental emissions from forage-based dairy farms. Agricultural and Food Science, 22, 93-107.

Moate, P.J., Williams, S.R.O., Grainger, C., Hannah, M.C., Ponnampalam, E.N. and Eckard, R.J. (2011). Influence of cold-pressed canola, brewers grain and hominy meal as dietary supplements suitable for reducing enteric methane emissions from lactating cows. Animal Feed Science and Technology, 166/167, 254-264.

Patra, A.K. (2012). Enteric methane mitigation technologies for ruminant livestock: a synthesis of current research and future directions. Environmental Monitoring and Assessment, 184,1929-1952. 